«Parsadan Gorgijanidze's Exile in Shushtar: A Biographical Episode of a Georgian Official in the Service of the Safavids ». Journal of Persianate Studies $1,2,2008$, p. 218-229.

\title{
Giorgio Rota
}

\section{OpenEdition}

\section{Journals}

Édition électronique

URL : http://journals.openedition.org/abstractairanica/39397

DOI : 10.4000/abstractairanica.39397

ISSN : 1961-960X

Éditeur :

CNRS (UMR 7528 Mondes iraniens et indiens), Éditions de l'IFRI

Édition imprimée

Date de publication : 15 mai 2011

ISSN : 0240-8910

\section{Référence électronique}

Giorgio Rota, « « Parsadan Gorgijanidze's Exile in Shushtar: A Biographical Episode of a Georgian Official in the Service of the Safavids ». Journal of Persianate Studies 1, 2, 2008, p. 218-229. », Abstracta Iranica [En ligne], Volume 31 | 2011, document 155, mis en ligne le 11 octobre 2012, consulté le 26 septembre 2020. URL : http://journals.openedition.org/abstractairanica/39397 ; DOI : https://doi.org/ 10.4000/abstractairanica.39397

Ce document a été généré automatiquement le 26 septembre 2020.

Tous droits réservés 


\title{
«Parsadan Gorgijanidze's Exile in Shushtar: A Biographical Episode of a Georgian Official in the Service of the Safavids ». Journal of Persianate Studies 1, 2, 2008, p. 218-229.
}

\author{
Giorgio Rota
}

At the beginning of the article, Maeda states his opinion that many Safavid goläms were far from severing all ties with their homeland: here the Author agrees with the views of other modern Safavid scholars but he (rightly, in the opinion of the present reviewer) contradicts what one often reads in the scholarly literature concerning military slavery in the Muslim world in general. Maeda is also correct in stating that "by introducing the institution of the royal golāms, the Safavids imported local [Caucasian] politics" along with the golāms themselves (p. 227) and that, as a consequence, political influence between the two states was able to go both ways. The choice of Gorgijanidze as a topic for this article is especially important to drive these points home, because he was active not only as a Safavid court and administrative official, but also as a man of letters, writing in both Persian and, above all, in his mother tongue, Georgian. Maeda's study focuses in particular on one episode in Parsadan's life, namely, his exile in Šuštar, which in its turn is very likely to have been brought about by Parsadan's continuing involvement in Georgian domestic affairs. The exact reasons of the exile remain unclear (Parsadan blames the king of Kartli, Vaxt'ang $\mathrm{V}$ for his fall from grace but does not enter into details), but Maeda highlights circumstances (above all, the fact that Parsadan was a protégé of Vaxt'ang V's predecessor's, Rost'om Mepe and a failed bid for power over K'axeti, then ruled by a son of Vaxt'ang's, by a rival Georgian pretender) that may have caused it. In so doing, the Author sheds light also on the governor of Šuštar of the time, the Georgian Vāxušt Beyg/Vaxušt'i Baratašvili. Finally, the remark that "Parsadan possessed a dual sense of identity, as both a Georgian and a servant of the shah" (p. 226) is important and correct. Most of the details about Gorgijanidze's life 
and career are culled from his own history of Georgia, which confirms (if there was any need) the importance of Georgian sources for the history of the Safavid period.

2 Because of a misprint, King Vaxt'ang VI appears as Vaxt'ang IV (p. 219).

INDEX

Thèmes : 4.2.1. Safavides et Qâjârs

\section{AUTEURS}

\section{GIORGIO ROTA}

Institut für Iranistik - Wien 